\title{
Performance Characteristics of Cells Containing Two Potentiometric Sensors: Application to a Cell Containing Hydralazinium and Chloride Electrodes
}

\author{
Laila A. Al-Shatti \\ The Public Authority for Applied Education and Training \\ College of Nursing, P. O. Box 64923 Shuwaikh, Postal code 70466, Kuwait \\ Tel: 965-9978-8632 E-mail: fetoon3@hotmail.com \\ Hayat Marafie (Correspondening author) \\ Chemistry Department, Faculty of Science, Kuwait University \\ P.O. Box 5969 Safat, Postal Code 13060, Kuwait \\ Tel: 965-9970-1877Ｅ-mail: hayat.marafie@ku.edu.kw
}

Adel F. Shoukry

Chemistry Department, Faculty of Science, Kuwait University

P.O. Box 5969 Safat, Postal Code 13060, Kuwait

Tel: 965-9792-0693 E-mail: a.shoukry@ku.edu.kw

\begin{abstract}
Conventional plastic membrane electrode, selective to hydralazinium cation $(\mathrm{Hz})$ was constructed by incorporation of Hz-phosphotungstate ion associate in a poly(vinyl chloride) membrane. The influence of membrane composition, $\mathrm{pH}$ of the test solution and foreign ions on the cell performance was investigated. This was compared to the corresponding influence on a cell constructed by replacing the reference electrode in the conventional cell with Cl-selective electrode. The results indicated that the first cell showed Nernstian behavior, while the latter exhibited super Nernstian response. The selectivity for both cases was high. However the working $\mathrm{pH}$ range was narrower in case of the cell with two sensors.
\end{abstract}

Keywords: Hydralazinium-electrode, Phosphotungstate, Super Nerstian slope, Hydralazine hydrochloride, Plastic membranes

\section{Introduction}

Hydralazine hydrochloride (hydralazinium chloride, $\mathrm{HzCl}$ ) is an important pharmaceutical compound used as a vasodilator in the treatment of hypertension (Ellershaw and Gurney 2001; Li et al., 2010). In a previous work a $\mathrm{Hz}$-selective membrane electrode was prepared by incorporation of Hz-tetraphenylborate ion-pair into a poly(vinyl chloride) (PVC) matrix (Badawy et al., 1988). Although the electrode exhibited good performance characteristics, its life span was only about 2 hours. This created the demand to investigate the use of other ion-associates that are more lipophillic than Hz-tetraphynylborate, as ion-exchanger for the construction of plastic membrane Hz-electrodes of longer life times. This was done by introducing hydralazinium phosphotungstate $\left(\mathrm{Hz}_{3} \mathrm{PT}\right)$ ion associate as the ion-exchanger (Shoukry et al. 2006). The electrode showed Nernstian behavior over a life span of 17 days.

It was reported that one of the main disadvantages of direct potentiometry is the relatively high percent of error associated with slight indeterminate deviation of the reading (Christian 2004). Thus, for electrodes responsive to mono-, di-, and tri-valent ions; only $1.0 \mathrm{mV}$ deviation results in a 12.0, 8.0 and $4.0 \%$ error in the final determination, respectively. These error percentages were calculated assuming Nernstian behavior of the electrode. This drawback restricted the application of the traditional potentiometric technique using ion-selective electrodes especially for ions with high valency. However, the error can be, significantly decreased if the signal to noise ratio increased by increasing the graph slope. 
In the present paper, a new technique has been applied successfully by which calibration graph of multiple Nernstian slope, and consequently higher signal to noise ratio, is obtained. The new technique depends on employing cells containing two ion selective electrodes, one for $\mathrm{Hz}$ - and the other, in place of the reference, for the counter ion, Cl-. The latter was a polycrystalline silver chloride-based electrode (Hodrejarve 1985). The cell potential in this case is given by:

$$
\begin{gathered}
\mathrm{E}_{\text {cell }}=\mathrm{E}_{\mathrm{Hz}}-\mathrm{E}_{\mathrm{Cl}} \\
\mathrm{E}_{\text {cell }}=\left[\mathrm{E}_{\mathrm{Hz}}^{\mathrm{o}}+2.303 \mathrm{RT} / \mathrm{F}\left(\log \mathrm{a}_{\mathrm{Hz}}\right)\right]-\left[\mathrm{E}_{\mathrm{Cl}}^{\mathrm{o}}-2.303 \mathrm{RT} / \mathrm{F}\left(\log \mathrm{a}_{\mathrm{Cl}}\right)\right]
\end{gathered}
$$

where $\mathrm{E}^{\mathrm{o}}, \mathrm{R}, \mathrm{T}, \mathrm{F}$ and (a) have their familiar meanings.

For a dilute solution of $\mathrm{HzCl}, \quad \mathrm{a}_{\mathrm{Hz}}=\mathrm{a}_{\mathrm{Cl}}$,

$$
\begin{gathered}
\mathrm{E}_{\text {cell }}=\left(\mathrm{E}_{\mathrm{Hz}}^{\mathrm{o}}-\mathrm{E}_{\mathrm{Cl}}^{\mathrm{o}}\right)+2.303 \mathrm{RT} / \mathrm{F}\left(\log \mathrm{a}_{\mathrm{Hz}}\right)+2.303 \mathrm{RT} / \mathrm{F}\left(\log \mathrm{a}_{\mathrm{Cl}}\right) \\
\mathrm{E}_{\text {cell }}=\mathrm{E}_{\text {cell }}^{\mathrm{o}}+2(2.303 \mathrm{RT} / \mathrm{F})\left(\log \mathrm{a}_{\mathrm{Hz}}\right)
\end{gathered}
$$

Equation (4) shows that on plotting $\mathrm{E}_{\text {cell }}$ versus $\log \mathrm{a}_{\mathrm{Hz}}$, a straight line of double Nernstian slope is obtained, providing that the two sensors are functioning in a thermodynamic manner.

In a previous study (Shoukry, 1988) a cell containing two indicator electrodes was used for potentiometric titration of hexadecylpyridinium bromide with standard solution of sodium tetraphenylborate. Titration curves with sharp peaks or troughs, at the equivalence points, were obtained. Nevertheless, the study didn't include characterization of the cell's performance.

In the present work, the performance characteristics of cells containing two indicator electrodes are studied. Calibration graph's slope, stability and life span of the constructed cells as well as their responses towards changes of $\mathrm{pH}$ and presence of foreign ions have been investigated.

\section{Experimental}

\subsection{Reagents and Materials}

All chemicals used were of analytical grade. Bi-distilled water was used throughout all experiments. The Hz-PT ion-associate was prepared by a method similar to that described before by Shoukry et al. (1988). The composition of the produced ion-associate was determined by elemental analysis using Elementar Microcube. The agreement between calculated and found values was confirming the stoichiometry of (3:1) (Hz:PT).

\subsection{Construction of Electrodes}

\subsubsection{The chloride-selective electrode}

A silver rod of $10.0 \mathrm{~cm}$ length and $5.00 \mathrm{~mm}$ diameter was tightly insulated by polyethylene tube leaving $1.0 \mathrm{~cm}$ at one end for coating and $0.5 \mathrm{~cm}$ at the other end for connection. The $1.0 \mathrm{~cm}$ terminal was electrolytically coated with $\mathrm{AgCl}$. The coating was carried out in an $0.1 \mathrm{M} \mathrm{NaCl}$ solution with the silver rod as the anode and a platinum electrode of $1.0 \mathrm{~cm}^{2}$ surface area as the cathode. The coating time was 10 minutes with current density of about 10 $\mathrm{mA} / \mathrm{cm}^{2}$. The prepared electrode was preconditioned before use by soaking in a $10^{-2} \mathrm{M} \mathrm{NaCl}$ solution for 30 minutes.

\subsubsection{The plastic membrane Hz-selective electrode.}

In about $5 \mathrm{~mL}$ tetrahydrofuran, $5.0,10.0$ or $15.5 \mathrm{mg}$ of the ion-exchanger (Hz-PT) were dissolved and as well as $120 \mathrm{mg}$ of each of PVC and dioctylphthalate (DOP), as plasticizer and solvent mediator. The produced solution mixture was poured into a $7.5 \mathrm{~cm}$ diameter Petri dish and left to dry in air. The obtained membrane was used to prepare the electrodes as previously described by Issa et al. (1999); the internal solution of the electrode was $10^{-3}$ $\mathrm{M}$ in $\mathrm{HzCl}$ and $10^{-1} \mathrm{M}$ in $\mathrm{NaCl}$.

\subsection{Potentiometric Studies and Electrochemical Systems}

Potentiometric measurements were carried out with an Orion, Model $420 \mathrm{~A} \mathrm{pH} / \mathrm{mV}$ meter. A Caron circulator thermostat was used to control the temperature of the test solution. The following electrochemical systems were employed:

2.3.1 System containing one ion-selective electrode

$\mathrm{Ag}\left|\mathrm{AgCl}_{\text {(ref) }}\right| \mathrm{HzCl}$ Test solution | Plastic membrane $\left|\left(10^{-3} \mathrm{M}\right) \mathrm{HzCl},\left(10^{-1} \mathrm{M}\right) \mathrm{NaCl}\right| \mathrm{AgCl} \mid \mathrm{Ag}$ 


\subsubsection{System containing two ion-selective electrodes}

$$
\mathrm{Ag}\left|\mathrm{AgCl}_{\text {(coat) }}\right| \mathrm{HzCl} \text { Test solution | Plastic membrane }\left|\mathrm{HzCl}\left(0^{-3} \mathrm{M}\right)+\left(10^{-1} \mathrm{M}\right) \mathrm{NaCl}\right| \mathrm{AgCl} / \mathrm{Ag}
$$

\subsection{Construction of the Calibration Graphs}

Suitable increments of standard $\mathrm{HzCl}$ solution were added to $50 \mathrm{~mL}$ of $10^{-6} \mathrm{M} \mathrm{HzCl}$ solution to cover the concentration range of $10^{-6} \mathrm{M}$ to $1.7 \times 10^{-2} \mathrm{M}$. In this solution the sensor and the reference electrode or the two sensors were immersed and the emf was recorded after $10 \mathrm{~s}$, at $25^{\circ} \mathrm{C}$, for each addition.

\subsection{Selectivity}

The selectivity coefficients of the Hz- selective electrode, $\left(\mathrm{K}^{\mathrm{pot}} \mathrm{Hz,j}\right)$ or that of the cell containing $\mathrm{Hz}-$ and $\mathrm{Cl}-$ electrodes, $\left(\mathrm{K}_{\mathrm{Hz}, \mathrm{j}}^{\mathrm{pot}} \mathrm{k}_{\mathrm{Cl}, \mathrm{x}}^{\mathrm{pot}}\right)$ towards different cationic species $\mathrm{j}^{\mathrm{z+}}$ and different salts $\mathrm{j}_{\mathrm{n}}{ }^{\mathrm{t}} \mathrm{x}_{\mathrm{m}}{ }^{\mathrm{y}-}(\mathrm{nz}=\mathrm{my})$, respectively, were determined by the separate solution method (SSM) (Cosofret and Buck 1984) and matched potential method (MPM) (Ganjali et al. 2010).

\section{Results and Discussion}

\subsection{Composition of membrane}

Three membrane compositions were tried, in a previous work (Shoukry et al., 2006), as given in Table 1. The best responses over a relatively wide range of $\mathrm{HzCl}$ concentration are exhibited by electrodes made by using membranes containing $2.1 \%$ ion associate. The response time was always $<10 \mathrm{~s}$. However, membranes containing $4.0 \%$ ion-pair exhibited more stable readings, for this reason, electrodes made by using membranes of this composition (4\%) were selected for carrying out all consequent studies.

\subsection{Response characteristics of cell containing $\mathrm{Hz}$ - and reference electrodes}

The performance characteristics of Hz-selective electrodes were investigated as a function of soaking time. For this purpose the electrode was soaked in $10^{-3} \mathrm{M}$ solution of $\mathrm{HzCl}$ and the calibration graphs ( $\mathrm{pHz}$ vs $\mathrm{E}, \mathrm{mV}$ ) were plotted after different time intervals in a period of 17 days. The electrode proved reasonable activity throughout this period. The conditioning time required for activating the phase boundary exchange process at the surfaces of the membranes was 30 minutes with concentration range of $1.58 \times 10^{-5}-1.7 \times 10^{-2} \mathrm{M} \mathrm{HzCl}$ (Fig. 1a). On soaking the electrode for longer than 17 days, the calibration graph slope decreased gradually. This decrease in the response of the electrode is most probably due to leaching of the active ingredients from the gel layer at the membrane surface to the bathing solution and/or to appearance of asymmetry potential arises as a result of surface deformation. The results also reveal that the origin of plastic membrane electrode potential is phase-equilibrium at the interfacial junction separating the hydrated gel layer from the test solution (Pungor 2001) rather than an equilibrium associated with ionic transport through the membrane body ( Morf 2001).

\subsection{Response characteristics of cell containing two ion selective electrodes}

The cell produced calibration graphs of slopes of almost double Nernstian value. The cell attained stable potential within less than 10 seconds when the concentration of $\mathrm{HzCl}$ changed. The graphs were obtained at different intervals of soaking the electrodes in $10^{-3} \mathrm{M} \mathrm{HzCl}$ (Figure 1b). From this figure, it is evident that only 30 minutes of soaking is sufficient, as conditioning time, for the activation of the cell where a calibration graph of average slope of $107.16 \mathrm{mV} /$ concentration decade was obtained. The cell retained this slope over fourteen days of continuous soaking, after which a gradual decrease in the slope value was observed. Therefore, it is recommended to store the electrodes in a closed vessel in a refrigerator while not in use.

\subsection{Effect of $\mathrm{pH}$}

The effect of $\mathrm{pH}$ of the $\mathrm{HzCl}$ test solution on the potential reading is graphically represented in Figure 2. The $\mathrm{pH}$ of the initial solution is altered by the addition of small volumes of $\mathrm{HCl}$ and /or $\mathrm{NaOH}(0.1-1.0 \mathrm{M}$ each). For cell containing Hz-selective electrode and reference electrode (Fig. 2 a), the pH has negligible effect within a wide range of $\mathrm{pH}$-values extending from 3.2 - 9.4. In this range the electrode can be safely used for $\mathrm{Hz}$ determination without interference of Hydronium or hydroxyl ions. On the other hand, for cell containing $\mathrm{Hz}$ and $\mathrm{Cl}$-sensors (Fig. $2 \mathrm{~b}$ ), the working $\mathrm{pH}$ range of the cell was much narrower $(4.2-6.0)$. This may be attributed to the fact that the pH-change affects two working electrodes surfaces instead of one as in case of the traditional cell. From Fig. 2b, it is clear that at $\mathrm{pH}$-values higher than 6.0 , the cell potential increases gradually. This may be attributed to interference of the hydroxyl ions with chloride ions at the surface of the $\mathrm{AgCl}$-indicator electrode. This is confirmed by the fact that the cell potential change within this $\mathrm{pH}$-range was found to be reversible. This excludes the possibility of passivation of the $\mathrm{AgCl}$-electrode surface as a result of irreversible surface adsorption. 


\subsection{Selectivity}

\subsubsection{Cell containing Hz- and reference electrodes}

The selectivity of the Hz-responsive electrodes was studied by applying the separate solution (Cosofret and Buck, 1984) and the matched potential (Ganjali et al., 2010) methods as previously described. The selectivity coefficients towards $\mathrm{Na}^{+}, \mathrm{K}^{+}, \mathrm{Mg}^{2+}$ and $\mathrm{Cd}^{2+}$, as obtained by the separate solution method were $4.2 \times 10^{-3}, 5.8 \times 10^{-3}, 1.7 \times 10^{-3}$ and $9.20 \times 10^{-3}$, respectively. In case of applying the matched potential method, the corresponding values were $5.00 \times 10^{-2}, 5.3 \times 10^{-2}, 2.4 \times 10^{-2}$ and $3.30 \times 10^{-2}$, respectively. It is noticeable that the values obtained by the matched potential method are, in general higher than those obtained by the separate solution method, this may be attributed to the non-Nernstian behavior of the interfering ion in case of the separate solution method. However, the results, as obtained by the two methods, revealed high selectivity of the electrodes for $\mathrm{Hz}$ towards different cationic species.

\subsubsection{Cell containing Hz- and Cl- selective electrodes}

\subsubsection{Application of the separate solution method}

The cell potential is measured for two separate solutions, one containing $\mathrm{HzCl}$ of activity $\mathrm{a}_{\mathrm{Hz}}=\mathrm{a}_{\mathrm{Cl}}=10^{-3} \mathrm{M}, \mathrm{E}_{1}$, and the other containing the interferent salt $\mathrm{J}_{\mathrm{m}}{ }^{\mathrm{z+}} \mathrm{X}_{\mathrm{n}}{ }^{\mathrm{y}-}$, where $\mathrm{mz}=\mathrm{ny}$, and the activity $\mathrm{a}_{\mathrm{j}}=(\mathrm{m} / \mathrm{n}) \mathrm{a}_{\mathrm{x}}, \mathrm{E}_{2}$.

$$
\mathbf{E}_{1}=\left[\mathbf{E}_{\mathrm{Hz}}^{0}+(2.3 \mathrm{RT} / \mathrm{F}) \log \mathrm{a}_{\mathrm{Hz}}\right]-\left[\mathbf{E}_{\mathrm{Cl}}^{0}-(2.3 \mathrm{RT} / \mathrm{F}) \log \mathrm{a}_{\mathrm{Cl}}\right]
$$

where $E^{o}, R, T, F$ and (a) have their familiar meaning.

$$
\mathrm{E}_{1}=\mathrm{K}+(2.3 \mathrm{RT} / \mathrm{F}) \log \mathrm{a}_{\mathrm{Hz}} \mathrm{a}_{\mathrm{Cl}}
$$

where $\mathrm{K}=\mathrm{E}_{\mathrm{Hz}}^{\mathrm{o}}-\mathrm{E}_{\mathrm{Cl}}^{\mathrm{o}}$

$\mathrm{E}_{2}$ is given by Nicolsky (1937) equation,

$$
\begin{aligned}
& E_{2}=\left[E_{H z}^{0}+(2.3 R T / F) \log k^{p o t}{ }_{\mathrm{Hz}, \mathrm{J}}\left(\mathrm{a}_{\mathrm{J}}\right)^{\mathrm{m} / \mathrm{z}}\right]-\left[\mathbf{E}_{\mathrm{Cl}}^{0}-(2.3 \mathrm{RT} / \mathrm{F})\right. \\
& \left.\log \mathbf{k}^{\mathrm{pot}}{ }_{\mathrm{Cl}, \mathrm{X}}\left(\mathbf{a}_{\mathbf{X}}\right)^{\mathrm{n} / \mathrm{y}}\right] \\
& E_{2}=K+(2.3 R T / F) \log k^{p o t}{ }_{H z, J}+(2.3 R T / F) \log \left(a_{J}\right)^{\mathrm{m} / \mathrm{z}}+(2.3 R T / F) \\
& \log \mathrm{k}_{\mathrm{Cl}, \mathrm{X}}^{\mathrm{pot}}+(2.3 \mathrm{RT} / \mathrm{F}) \log \left(\mathrm{a}_{\mathrm{X}}\right)^{\mathrm{n} / \mathrm{y}} \\
& \mathrm{E}_{2}=\mathrm{K}+(2.3 \mathrm{RT} / \mathrm{F}) \log \mathrm{k}^{\mathrm{pot}}{ }_{\mathrm{HZ}, \mathrm{J}} \quad \mathrm{k}^{\mathrm{pot}}{ }_{\mathrm{Cl}, \mathrm{X}}+(2.3 \mathrm{RT} / \mathrm{F}) \log \left(\mathrm{a}_{\mathrm{J}}\right)^{\mathrm{m} / \mathrm{z}}\left(\mathrm{a}_{\mathrm{X}}\right)^{\mathrm{n} / \mathrm{y}}
\end{aligned}
$$

From (6) and (9),

$$
\begin{aligned}
& (2.3 R T / F) \log \mathbf{k}^{\text {pot }}{ }_{\mathrm{Hz}, \mathrm{J}} \quad \mathrm{k}^{\mathrm{pot}}{ }_{\mathrm{Cl}, \mathrm{X}}=\left(\mathrm{E}_{2}-\mathrm{E}_{1}\right)+(2.3 \mathrm{RT} / \mathrm{F}) \log \mathrm{a}_{\mathrm{Hz}} \mathrm{a}_{\mathrm{Cl}}- \\
& (2.3 R T / F) \log \left(a_{J}\right)^{m / z}\left(a_{x}\right)^{n / y} \\
& \log \mathbf{k}_{\text {cell }}^{\text {pot }}=\left(E_{2}-E_{1}\right) /(2.3 R T / F)+\log a_{H z} a_{C l}-\log \left(a_{J}\right)^{m / z}\left(a_{x}\right)^{n / y}
\end{aligned}
$$

$\mathrm{k}^{\mathrm{pot}}{ }_{\text {cell }}$ is the selectivity coefficient of the cell $\left(\mathrm{k}^{\mathrm{pot}}{ }_{\mathrm{Hz}, \mathrm{J}} \quad \mathrm{k}^{\mathrm{pot}}{ }_{\mathrm{Cl}, \mathrm{X}}\right)$.

It is noticeable that equation (11) is corresponding to the following equation which is applied for a cell containing one sensor electrode (Issa et al., 1999)

$$
\log \mathrm{k}_{\mathrm{Hz}, \mathrm{J}}^{\mathrm{pot}}=\left(\mathrm{E}_{2}-\mathbf{E}_{1}\right) /(2.3 \mathrm{RT} / \mathrm{F})+\log \mathbf{a}_{\mathrm{Hz}}-\log \mathbf{a}_{\mathbf{J}}{ }^{\mathrm{z}}
$$

The obtained $\log \mathrm{k}^{\mathrm{pot}}$ cell values are given in Table (3). The results revealed high selectivity of the cell containing two sensors for $\mathrm{HzCl}$ towards different inorganic salts.

\subsubsection{Application of the matched potential method.}

The selectivity of the cell was measured by determining the concentration ratio of $\mathrm{HzCl}$ and the interfering salt $\mathrm{J}_{\mathrm{m}}{ }^{\mathrm{+}}$ $\mathrm{X}_{\mathrm{n}}^{\mathrm{y}}{ }^{-}$that causes the same potential change when added to a reference $\mathrm{HzCl}$ solution. Thus, the change in potential was measured upon changing $\mathrm{HzCl}$ concentration, then the interfering salt was added to an identical reference solution until the same potential change was obtained. The method (Ganjali, 2010) is recommended by IUPAC. It 
has the advantage that it gets rid of the limitations of the other methods based on the Nicolsky-Eisenman equation (Girault, 2004, and Koryta, 1986). The main limitation is the non-Nernstian behavior of the interfering ions. According to this method, the selectivity coefficient is calculated as the selectivity ratio of the primary molecule $(\mathrm{HzCl})$ and the interfering salt $\mathrm{J}_{\mathrm{m}}{ }^{{ }^{+}} \mathrm{X}_{\mathrm{n}}^{\mathrm{y}-}$ that gives the same potential change in a reference solution,

$$
\mathbf{k}_{\text {cell }}^{\text {pot }}=\Delta \mathbf{C}_{\mathrm{HzCl}} / \mathbf{C}_{\mathrm{JmXn}}
$$

where $\Delta \mathrm{C}_{\mathrm{HzCl}}$ and $\mathrm{C}_{\mathrm{JmXn}}$ are the change in $\mathrm{HzCl}$ concentration and the concentration of the interfering salt that cause the same potential change in a reference solution of $\mathrm{HzCl}$.

Collective results of $\mathrm{k}^{\text {pot }}{ }_{\text {cell }}$ obtained for the investigated cells towards $\mathrm{NaCl}, \mathrm{KCl}, \mathrm{NaNO}_{3}, \mathrm{KNO}_{3}, \mathrm{CH}_{3} \mathrm{COONa}_{3}$, $\mathrm{MgCl}_{2}, \mathrm{Na}_{2} \mathrm{SO}_{4}, \mathrm{Cd}\left(\mathrm{NO}_{3}\right)_{2}, \mathrm{Mg}\left(\mathrm{NO}_{3}\right)_{2}$ and $\mathrm{MgSO}_{4}$ as obtained by the separate solution and matched potential methods are given in Table (3). The results revealed that the proposed cells showed comparable selectivity coefficients by applying the two methods although the values obtained by the MPM were, in general, slightly lower than those by the SSM. It is also noteworthy that the values of $\mathrm{k}^{\mathrm{pot}}{ }_{\text {cell }}$ for monovalent salts are higher than those for salts containing divalent ions, this can be explained on the base that electrostatic nature of monovalent salts in its hydrated forms is more relevant to those of a hydralazinium chloride than divalent ions-containing salts.

\section{Conclusion}

Potentiometric cells, containing two ion selective electrodes, one for Hz- and the second for $\mathrm{Cl}-$, exhibit comparable performance characteristics to those of cells containing $\mathrm{Hz}$ and a reference electrode. However, these cells exhibit calibration graphs $\left(\mathrm{E}_{\text {cell }}\right.$ versus $\mathrm{pHz}$ ) with slopes of about double Nernstian values.

\section{Acknowledgement}

The authors would like to acknowledge Kuwait University support for providing the facilities of ANALAB (grant no. GS01L01) and SAF (grant no. GS03/01).

\section{References}

Badawy, S.S., Shoukry, A. F., Rizk, M.S., and Omar M.M. (1988). Hydralazine-selective PVC membrane electrode based on hydralazinium tetraphenylborate. Talanta, 35(6), 487-489.

Christian, G. D. (2004). Analytical Chemistry, John Wiley \& Sons, Inc. $6^{\text {th }}$ Edn., p. 383.

Cosofret, V. V. and Buck, R. P. (1984). Phenothiazine drug poly (vinyl chloride) matrix membrane electrodes and their use in pharmaceutical analysis. Analyst, 109, 1321-1325.

Ellershaw, D. C. \& Gurney, A. M. (2001). Mechanisms of hydralazine induced vasodilation in rabbit aorta and pulmonary artery. British Journal of Pharmacology, 134, 621-631.

Ganjali, M. R., Faridbod, F., Larijani, B., Riahi, S., Hosseini, M., Esfahani, E. N. \& Norouzi, P. (2010). Terazosin potentiometric sensor for quantitative analysis of terazosin hydrochloride in pharmaceutical formulation based on computational study. Int. J. Electrochem. Sci., 5, 200-214.

Girault, H. H. (2004). Analytical and physical electrochemistry, EPFL Press, Marcel Dekker, Inc., NY 10016, USA.

Hodrejarv, H. (1985). Ion-selective Electrodes 4, Ed. E. Pungor, Elsevier Science Publishers, The Netherland, p. 449.

Issa, Y.M., Abdel-Ghani, N. T., Shoukry, A.F. and Ahmed, H. M. (1999). Amineptine plastic membrane electrode based on its ion-associate with tetraphenylborate and phosphomolybdic acid. Mikrochimica Acta, 132, 83-88.

Koryta, J. (1986). Ion-selective electrodes. Annual Review of Materials Science. 16, 13-27.

Li, Y., Saito, Y., Kuwahara, K., Rong, X., Kishimoto, I., Harada, M., Horiuchi, M., Murray, M. \& Nakao, K. (2010). Vasodilator therapy with hydralazine induces angiotensin AT2 receptor-mediated cardiomycocyte growth in mice lacking guanylyl cyclase-A. British Journal of Pharmacology, 159, 1133-1142.

Morf W. E. (1981). The Principles of Ion-selective Electrodes and of Membrane Transport, Akademiai Kiado, Budapest, p.115.

Pungor, E. (2001). The new theory of ion-selective electrodes. Sensors, 1, 1-12.

Shoukry, A. F. (1988). Use of two ion-selective electrode-containing cells for potentiometric titration of hexadecylpyridinium bromide. Analyst, 113, 1305-1308. 
Shoukry, A.F., Badawy, S.S. and Farghali, R. (1988). Hexadecylpyridinium-phosphotungstate ion association in construction of a hexadecylpyridinium cation selective electrode. Anal. Chem., 60, 2399-2402.

Shoukry, A.F., Marafie, H. M., El-Shatti, L. A. (2006). X-ray photoelectron spectroscopy and electron microscopy of hydralazinium ion-selective electrode membrane's surface. Electroanalysis, 8, 779-785.

Table 1. Effect of membrane composition on Hz-electrode performance (30 minutes soaking)

\begin{tabular}{|c|c|c|c|c|c|}
\hline $\begin{array}{c}\text { Ion pair } \\
\%(\mathrm{mg})\end{array}$ & $\begin{array}{c}\text { DOP } \\
\%(\mathrm{mg})\end{array}$ & $\begin{array}{c}\text { PVC } \\
\%(\mathrm{mg})\end{array}$ & $\begin{array}{c}\text { Range } \\
\mathrm{M}\end{array}$ & Slope* & $\begin{array}{c}\text { Response } \\
\text { Time, sec }\end{array}$ \\
\hline 2.0 & 48.98 & 48.98 & $2.74 \times 10^{-6}-1.70 \times 10^{-2}$ & 56.67 & $<10$ \\
$(5.0)$ & $(120)$ & $(120)$ & & & $<10$ \\
\hline 4.0 & 48.00 & 48.00 & $1.58 \times 10^{-5}-1.70 \times 10^{-2}$ & 53.80 & $<10$ \\
$(10.0)$ & $(120)$ & $(120)$ & & & \\
\hline 6.1 & 46.97 & 46.98 & $9.33 \times 10^{-6}-1.70 \times 10^{-2}$ & 49.67 & \\
$(15.5)$ & $(120)$ & $(120)$ & & & \\
\hline
\end{tabular}

$* \mathrm{mV} / \mathrm{Hz}$ concentration decade

Table 2. Effect of soaking on Hz-electrode performance

\begin{tabular}{|c|c|l|}
\hline Soaking time & Slope & \multicolumn{1}{c|}{$\begin{array}{c}\text { Concentration range } \\
(\mathbf{M})\end{array}$} \\
\hline 0.5 hour & 53.80 & $1.58 \times 10^{-5}-1.7 \times 10^{-2}$ \\
\hline 1 hour & 55.490 & $3.16 \times 10^{-6}-1.7 \times 10^{-2}$ \\
\hline 2 hours & 55.000 & $6.31 \times 10^{-6}-1.7 \times 10^{-2}$ \\
\hline 24 hours & 54.030 & $4.00 \times 10^{-6}-1.7 \times 10^{-2}$ \\
\hline 48 hours & 57.640 & $1.26 \times 10^{-6}-1.7 \times 10^{-2}$ \\
\hline 72 hours & 60.030 & $6.31 \times 10^{-6}-1.7 \times 10^{-2}$ \\
\hline 8 days & 63.011 & $1.00 \times 10^{-6}-1.7 \times 10^{-2}$ \\
\hline 10 days & 59.990 & $6.31 \times 10^{-6}-1.7 \times 10^{-2}$ \\
\hline 17 days & 54.980 & $6.31 \times 10^{-6}-1.7 \times 10^{-2}$ \\
\hline
\end{tabular}

* $\mathrm{mV} / \mathrm{Hz}$ concentration decade

Table 3. Selectivity coefficients, $K_{\mathrm{Hz}, \mathrm{j}} K_{\mathrm{Cl}, \mathrm{X}}$, of a cell containing $\mathrm{Hz}$ and $\mathrm{Cl}^{-}$selective electrodes, for $\mathrm{HzCl}$ towards inorganic salts, at $25^{\circ} \mathrm{C}$

\begin{tabular}{|c|c|c|}
\hline Interferent & SSM $^{*}$ & MPM $^{* *}$ \\
\hline $\mathrm{NaCl}$ & $1.90 \times 10^{-1}$ & $8.30 \times 10^{-3}$ \\
\hline $\mathrm{KCl}$ & $2.40 \times 10^{-1}$ & $9.79 \times 10^{-3}$ \\
\hline $\mathrm{NaNO}_{3}$ & $1.20 \times 10^{-2}$ & $2.08 \times 10^{-3}$ \\
\hline $\mathrm{KNO}_{3}$ & $1.23 \times 10^{-2}$ & $4.59 \times 10^{-3}$ \\
\hline $\mathrm{CH}_{3} \mathrm{COONa}_{2}$ & $1.10 \times 10^{-2}$ & $3.95 \times 10^{-3}$ \\
\hline $\mathrm{Na}_{2} \mathrm{SO}_{4}$ & $5.86 \times 10^{-3}$ & $3.48 \times 10^{-3}$ \\
\hline $\mathrm{MgCl}_{2}$ & $1.27 \times 10^{-1}$ & $8.40 \times 10^{-3}$ \\
\hline $\mathrm{MgSO}_{4}$ & $0.37 \times 10^{-2}$ & $1.31 \times 10^{-3}$ \\
\hline $\mathrm{Mg}\left(\mathrm{NO}_{3}\right)_{2}$ & $7.46 \times 10^{-3}$ & $2.38 \times 10^{-3}$ \\
\hline $\mathrm{Cd}\left(\mathrm{NO}_{3}\right)_{2}$ & $2.23 \times 10^{-3}$ & $1.14 \times 10^{-3}$ \\
\hline
\end{tabular}

*Separate solution method.

**Matched potential method 


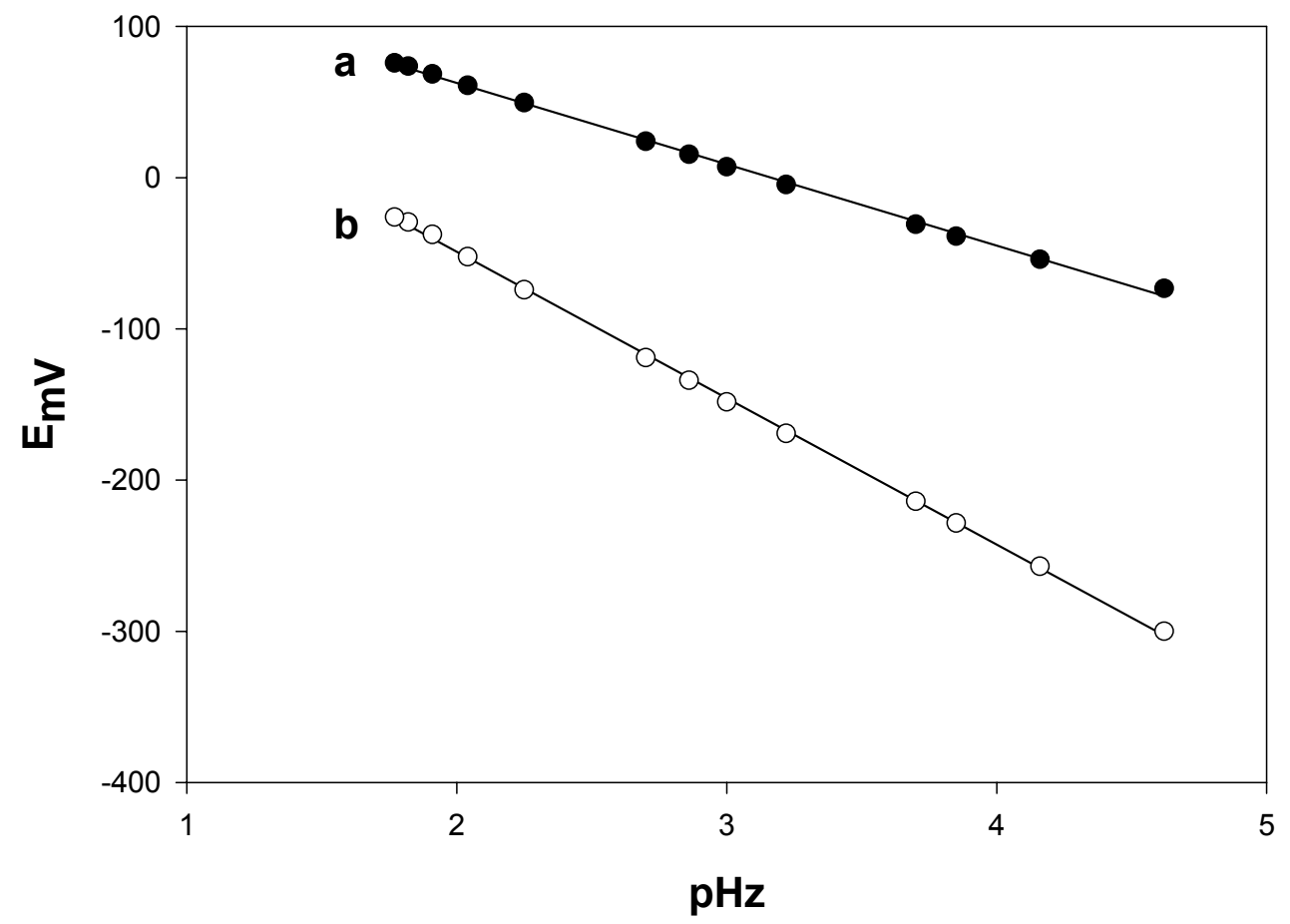

Figure 1. Calibration graphs obtained after 30 minutes conditioning time for (a) cell containing $\mathrm{Hz}$ - and reference electrode and (b) cell containing $\mathrm{Hz}$ - and $\mathrm{Cl}$ - selective electrodes

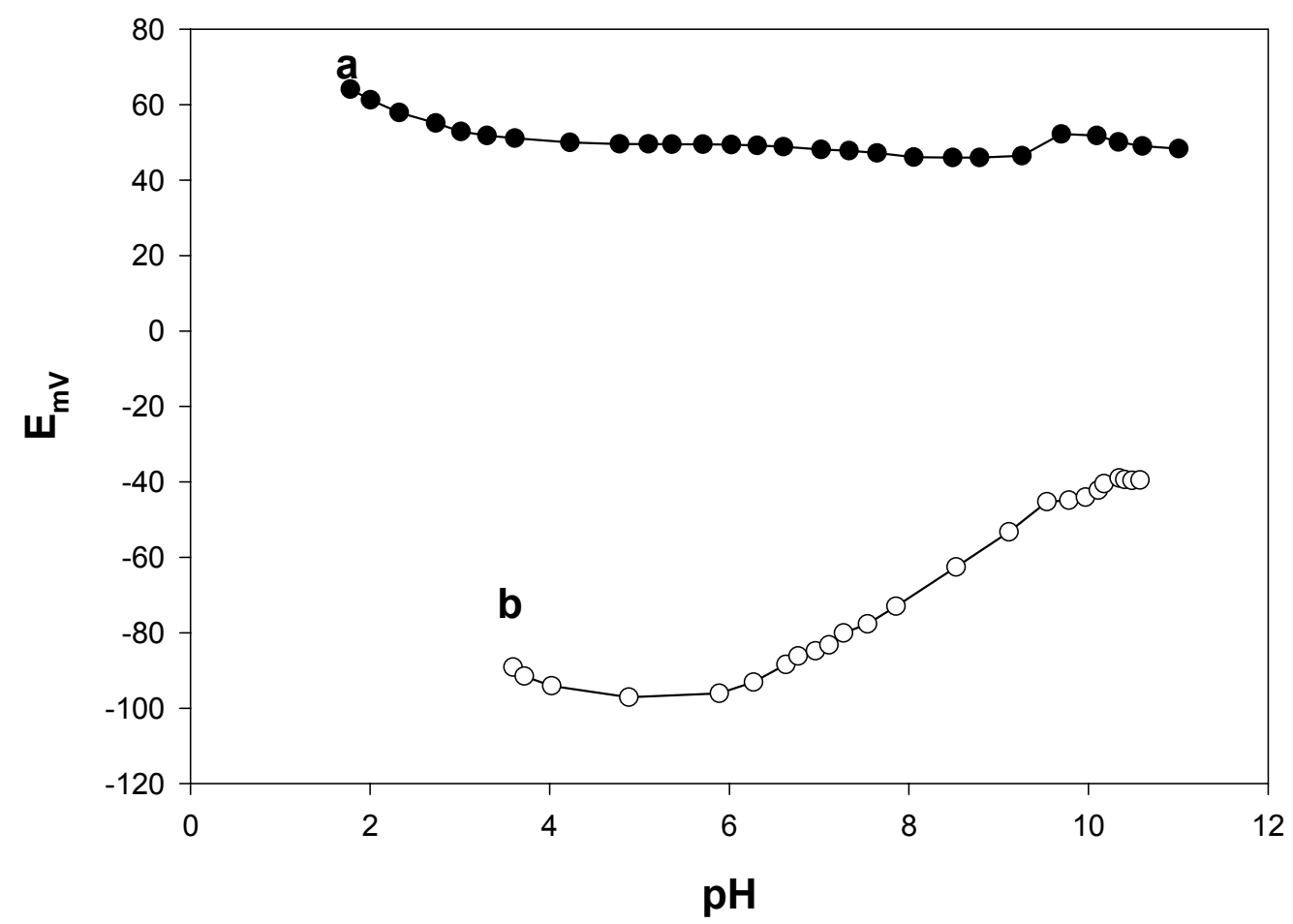

Figure 2. Effect of $\mathrm{pH}$ of the test solution on the potential of (a) cell containing Hz- and reference electrodes and (b) cell containing $\mathrm{Hz}$ - and $\mathrm{Cl}$ - responsive electrodes 